\title{
The Influence of Managerial Competencies on the Business Performance in the Small Business Funded by Jordan River Foundation
}

\author{
Emad Y. Masoud ${ }^{1 *} \quad$ Lana Al khateeb ${ }^{2}$ \\ 1.Department of Management, Higher Colleges of Technology, Abu Dhabi, UAE \\ 2.Business Department, Middle East University, Amman, Jordan
}

\begin{abstract}
Rapid changes in the business environment are associated with the development of managerial competencies within organizations. Small and medium enterprises (SMEs) are critical in the economic and social development of most countries. The relationship between managerial competencies and organizational performance remains an important issue within organizational literature. However, there were limited studies conducted to assess the relationship between managerial competencies and organizational performance on small and medium enterprises. For this reason, this study aimed to determine whether there is a significant relationship between managerial competencies and the business performance in the small businesses funded by the Jordan River Foundation in Jordan. The empirical approach consists of data collection through the use of a self-administered questionnaire in a survey. A structured questionnaire was administered to 220 managers of small businesses funded by the Jordan River Foundation to establish the influence of their managerial competencies on the performance of their businesses. A total of 176 questionnaires were retrieved and analyzed by using the SPSS program for the statistical analysis, to reach the results of this study. The results revealed that managerial competencies are significantly correlated to business performance. There is a significant relationship between managerial competencies (Communication, Planning, and organizing) and efficiency. Three assortments of managerial competencies were evident to influence sales, namely, communication, planning and organizing, and customer focus. There is a significant relationship between managerial competencies (communication, team building, and customer focus) and customer satisfaction. The result will help the managers on how their competencies support and contribute to the firm's overall success as well as their improvement in the organization.
\end{abstract}

Keywords: Managerial competencies, business performance, small businesses, Jordan River Foundation.

DOI: $10.7176 / \mathrm{EJBM} / 12-20-06$

Publication date:July $31^{\text {st }} 2020$

\section{Introduction}

Over the years many studies tried to identify the term competency and its influence on business performance. On one hand, competency is a set of skills, related to knowledge, attitudes, and attributes that allow an individual to perform a task or an activity within a specific function or job. Managerial competencies are activities, knowledge, skills, attitudes, or personal characteristics necessary to improve management performance. It is better to observe what good performers do to be successful, rather than making assumptions about intelligence and other underlying traits. On the other hand, the performance of the managers and their employees considered the most important element that affects the company's success. It is a combination of management and analytic processes that allows managers of an organization to achieve pre-determined goals. A large number of studies have been conducted on small business performance. Its dimensions play an important role in influencing small business growth. The managerial competency helps small projects to stay longer as possible as it can in a competitive environment. Every business has its competencies which give it a competitive advantage in the market. Upon that, this study discussed the influence of managerial competencies on business performance by clarifying its dimensions and reviewing the significant studies related to the factors influencing the managerial competencies among it. Boyatzis (1982) defined competencies as a human ability to behave in a way to meet job requirements in parameters given by the organization's environment and thus to achieve the required results. He defined threshold competencies as competencies crucial for managerial work, however, not having any significant causal relationship to its efficiency and better results. Ulrich, \& Lake (1991) believed that to perform better, people need to know what set of skills are needed to achieve high performance. Basic competencies are defined as knowledge and skills essential for the performance of a manager's job. They relate to specific tasks and guarantee the manager's efficiency. Highperformance competencies are further subdivided into cognitive, motivational, directional, and performance competencies. Hogg (2001) adds that managerial competencies lead to the demonstration of skills and abilities, which result in effective performance within an occupational area.

Research on competencies went to analyze, understand, and explain the importance of managerial competencies in organizations (Minsky \& Kaufman, 2008). Many models of managerial competencies have been developed in the last thirty years (Boyatzis, 1982). Though, organizations applying several models of competencies 
during the work, but still need to determine the most effective model to considerer it as essential for good achievements. Jordan River Foundation is none profitable and non-governmental organization established in 1995 by the Queen of Jordan, her majesty Queen Rania Al Abdullah for supporting local-small projects that create opportunities for people in local communities. The program in this foundation provides training and capacity building to ensure that local communities have the knowledge, tools, and resources needed to be self-reliant and sustainable to give a good performance. This study aims to serve better outcomes on managerial competencies in the small projects in this foundation. This study has discussed the various managerial dimensions that influence organizations' performance.

\section{Literature Review}

\subsection{Managerial competencies}

The term competency has been known in the early nineties. The first thoughts were focused on that any business can improve its experiences and its knowledge skills to show that it has an importance to give a competitive advantage in the market. While Heene \& Sanchez (1997) defined competency as the developing and practicing a unique set of skills ahead of its competitors. Smart (1999) listed other critical competencies of top managers which primarily include intelligence, analytical skills, strategic skills, judgment and decision making, risk-taking, excellence, team player, communications, assertiveness, ambition, adaptability, creativity, vision, and balance in life. Hoffmann (1999) suggests that the purpose of defining competencies is to improve human performance in three main outcomes i.e. observable performance, the quality of the outcome of the person's performance, and the underlying attributes of a person largely encompass the concept. Abraham et al. (2001) identified another six critical competencies; leadership skills, customer focus, result orientation, problem-solving, communication skills, and team leader to be an effective manager. Hellriegel, et al. (2005) added that communication competency, planning and administration competency, teamwork competency, strategic action competency, global awareness competency, and self-management competency as the six core managerial competencies which are required to be an effective manager to give high performance. From this side, every business should hold on a special kind of competencies which leading it to success. Rao (2007) identified 12 qualities of effective Indian leaders i.e. communication, competence, decision making, humility and love, compassion, vision, team-work, training, stamina, integrity, courage, and man-management. Qiao and Wang (2008) found that team building, communication, coordination, execution, continual learning is the most critical managerial competencies for the success of middle managers in China and they require a different set of competencies from senior managers. Chong (2011) said that managerial competencies required for normal and superior performance determine managerial competency models. These performance-based competencies are assessed through observed behaviors. Krajcovicova, et al. (2012) defines managerial competencies as a "bunch of knowledge, skills, experience, and characteristic, which support the achievement of the objective and he added a combination of knowledge, skills, abilities, and behaviors that an employee uses in carrying out their work and they are critical to achieving results which are consistent with the strategic goals of the organization. Bhardwaj \& Punia (2013) listed competencies of top managers which include intelligence, analytical skills, strategic skills, judgment and decision making, risktaking, excellence, team player, communications, assertiveness, ambition, adaptability, creativity, vision, and balance in life. In this study the dimensions of managerial competency have been determined: Communication competency, Planning, and organizing, Strategic thinking and scenario building, Planning and organizing, Teamwork competency, Customer focus.

2.1.1 Communication competency

It is an ability to choose the right is written and oral, formal and informal, and intentional and unintentional communication as well as to take into consideration the specific speaking situation (Chion-Kenney, 1994). It has two criteria oral and written communication skills, mediation, and negotiation that every employee in business should speak fluently and confidently when they present information or responding to the needs of the customers. And always have alternatives to them. The communication competency strengthens the foundation for successful management. It also enables managers to lead others that they couldn't do so without communicating their ideas well (Casimir and Waldman, 2007). The model used to describe communication competency is the component model which includes three components: knowledge, skill, and motivation. Knowledge simply means knowing what behavior is best suited for a given situation, skill is having the ability to apply that behavior in the given context; motivation is having the desire to communicate effectively. So, this helps communicators be able to recognize what communication practice is appropriate (knowledge), can perform that practice (skill), and want to communicate effectively and appropriately (motivation).

2.1.2 Planning and organizing

Planning and organizing have three criteria (quality focus, analysis, and problem-solving, drive for result) to reach any business goal it should set high standards for quality on the product and the whole work, also be prepared for contingencies by identifying problems factors and monitoring plans to take corrective actions as required then organizing things that are well planned, and well-monitored; that means working with employees to clarify broad 
objectives by developing plans and schedules to achieve goals efficiently. Which need time management by keeping changes scheduled to rely on, when it is necessary as a backup plan to reduce the pressure of the work. Managers should pay attention to the organization's financial issues before putting any plan to meet future expectations. Effectively plan what is to be achieved and properly coordinate and involve all relevant stakeholders. The key here is being able to demonstrate that you can determine the necessary sequence of activities and the efficient level of resources required to achieve both short and long term goals (Kouzes and Posner, 1995).

2.1.3 Strategic thinking and scenario building

Minsky \& Kaufman (2008) view strategic thinking as "practical dreaming" in the way in which people in an organization assess, view, and create the future for themselves and their associates by defining and envisioning results that add value to their business.

Strategic thinking and scenario building have three criteria (innovative and creation, risk and time management, competitive strategy) that managers should be sensitive to the business priorities through exploring and understanding opportunities and risks that could affect services, products or jobs, then designing alternative scenarios by discovering new ways of doing things and improve traditional ways with more effective actions with using time effectively through seeking information for organizations mission and objectives especially business environment towards competitors, to lead rather than follow them, create a dynamic environment, consult the technical levels for right decision making, and to have a cognitive and the ability to direct organization strength to response directly for an emergency (Sparrow, 2006). Strategists such as Haycock (2012) added that strategic thinking is applying activity that can be developed in individuals across all levels of an organization, so that their creativity and innovation may become integrated into the formal organizational strategic planning process.

2.1.4 Teamwork competency

Teamwork competency has two criteria mentoring and coaching. Managing small organizational group that goes with showing respect, empathy for the views of the other team members, supporting them by sharing wisdom and professional expertise with others, and building team spirit and strong relationship with others. It can affect employees' performance and encourage to provide beyond the expectations for a good result, by setting the required tasks and show the positive returns through having the right combination of talents and competencies to acquire the resources they need to be effective. Managers can develop their employees' teamwork competency from all level of the organization including members of the team, those who will administer the plan, and even customers through understanding the strength and weaknesses of the team and use their strength to fulfill their weaknesses (Ulrich, et al., 2000).

2.1.5 Customer focus

It has three criteria that deliver a service, seeks customer feedback to add value and understand customer requirements. All employees must demonstrate a full understanding of customer needs and expectations to enable the effective delivery and development of appropriate quality services that meet customer expectations by identifying customer needs by taking into account their diverse needs (Kotler \& Armstrong, 2007). Consistently makes decisions focused on the customer, seeking customer feedback to investigate ways to improve customer experience, creating an environment where teams are empowered to put customers first, and then makes sure the organization works to resolve issues most important to customers. As a result, customer focus competency leading to customer satisfaction and loyalty that affect the organization's performance (Bueren, et al., 2004).

\subsection{Business performance}

Business performance is related to the strength of the company, that the performance translates the organization's task and its strategies to procedures. Supreme departments in business organizations still thinking of performance subject as long these organizations are existing and being busy on measuring its basic rules. Cockerill (1989) suggested that management performance is related to managers themselves than to their positions and authority within the organizations. Harold (1993) argues that the performance of a manager (output competencies) is influenced by their job-related knowledge and experience (input competencies), and personality characteristics (process competencies). While performance was defined as a continuous totalitarian activity which reflects the successes of the economic unity and its continuity, also its ability to adapt to the environment or failing according to the basis of specific criteria laid down by the economic unit under the requirements of its activities in the light of long-term goals (Riketta, 2002). Performance is a wide concept, and its content is renewed and variable which improves any content of the organization even if it was different. Even there are many studies and researches about business performance but there was not an agreement on a specific definition of performance (Armstrong, 2006). Gladon and Augustine (2008) found that there is a strong relationship between the managerial competencies of an organization and its marketing effectiveness. The findings of the study have identified four "Supra competency" clusters i.e. conceptualize, align, interact, and create success associated with high performance. According to their study, 'Motivation' emerged as the most important single predictor of variance in performance and was the only characteristic that differentiates the top performers from the bottom performers. It has been noticed that the performance of a manager is highly influenced by his or her competencies and thus the success of an organization 
depends upon managers' competencies. Masoud and Alzayat (2012) found that there is a significant effect of top management support on front line employees' performance. The performance is defined as the outputs and actions that the organization can work towards to achieve the goals set by the senior administrations and based on the strategic planning in advance. It links the various activities of the organization with the objectives achieved. This is done by accomplishing the tasks to the fullest (Durrani et al, 2011). Performance is the net effect of an individual's efforts to that amount starts together with the advantage then perceives the role then tasks. This skill to that amount overall performance is the result of the interrelationship between effort, capacity, and the position and tasks assigned by it. A performance appraisal function in any organization is one of the main functions that human resources management must perform, providing all of them with the necessary information to perform their roles in the direction that achieves the latter's objectives. The objectives of the institution are to coordinate and cooperate with the managers of other departments, and the weakness of the members of the organization and achieve satisfaction among them and their psychological stability and their full confidence in the administration and their keenness to achieve their goals. In this study, the outcomes of business performance were determined by: A- Efficiency: It is the ability to avoid wasting materials, energy, efforts, money, and time in doing something or in producing the desired result. In a more general definition, it is the ability to do things well, successfully, and without waste. In scientific terms, it is a measure of the extent to which input is well used for an intended task or function (output). Efficiency was measured with a five-item scale from Sethi and King (1994) this scale assessed improvements in production and marketing efficiency.

B- Sales performance: It is the practice of monitoring and guiding personnel to improve their ability to sell products or services and defining, clearly communicating sales strategies and objectives, also prescribing roles and sales processes consistent with how a company plan to deliver value to its customers. According to the whole organization, it's a comprehensive solution that helps organizations drive sales alignment from strategy through to execution while improving efficiency, accuracy, and timeliness of the associated administrative processes. Sales performance was measured with a five-item scale adapted from (Venkatraman and Ramanujam, 1986), this scale assessed increases in market share, sales volume, customer acquisition, and customer retention.

C- Customer satisfaction: high customer satisfaction translates to customer loyalty, and loyalty is one of the biggest drivers of corporate growth. Every company needs to examine the customer's interactions with their products and services through a different lens and discover where these falling short (Sethi and King, 1994). Customer satisfaction is the most important variable that every company gives it too much attention because without customers the company can't survive in the market and can't gain a competitive advantage (Masoud, 2020). So managers focus on ways to bring more customer and they try to avoid any risk that may cost them losing their reputation which affects their customers.

According to the researchers' visit to the Jordan River Foundation and taking permission to have a look on the data that has been collected from its managers who supervised the small businesses funded by Jordan River Foundation, many projects have been succeeded after certain training but without determining the main dimensions to give better performance for their projects. Also, some of them has been failed there were approximately $14 \%$ failed projects (Jordan River foundation data). So, the problem of this study is to change this fact from failed projects to successful ones through determining the main dimensions of managerial competency that influence on business performance, by suggesting the following hypotheses.

H1: Overall managerial competency (communication, planning and organizing, strategic thinking and scenario building, teamwork, customer focus) has a positive influence on business performance.

H11: Managerial competency (communication, planning and organizing, strategic thinking and scenario building, teamwork, customer focus) has a positive influence on efficiency.

H12: Managerial competency (communication, planning and organizing, strategic thinking and scenario building, teamwork, customer focus) has a positive influence on sales performance.

H13: Managerial competency (communication, planning and organizing, strategic thinking and scenario building, teamwork, customer focus) has a positive influence on customer satisfaction.

\section{Background of Research}

Abraham et al. (2001) investigated two general questions concerning managerial competencies and performance appraisal: whether a set of managerial competencies currently being used by organizations to describe successful managers can be identified; and whether organizations are appraising these same competencies as part of their managerial performance appraisal processes. The six competencies most often identified as critical to managerial success appear to be proper choices, given the discussion of the attributes needed for competency to be effective. The sample was School of Business, the State University of New York at Oswego, New York, USA. The results showed that many of these same organizations are not appraising these competencies in their managerial performance appraisal processes. Collins and Clark (2003) examined the relationships between a set of networkbuilding HR practices, aspects of the external and internal social networks of top management teams, and firm performance. The result from a sample of 73 high-technology firms, showed that the relationships between the HR 
practices and firm performance (sales growth and stock growth) were mediated through their top managers' social networks. Xuejun and Wang (2009) aimed to identify managerial competencies required for successful middle managers in China. Data were collected by a questionnaire survey distributed among MBA and EMBA students at a major university in China. The findings of this study suggest that team building, communication, coordination, execution, and continual learning are critical competencies for the success of middle managers in China. Chye et al. (2010) showed that integration exists between innovativeness and managerial competencies to influence SME performance in Malaysia, and the moderating effect of managerial competencies on the relationship between innovativeness and SME performance in Malaysia. The findings provide managerial implications and strategic recommendations to entrepreneurs, owner-managers, and policymakers in the SME sectors. Lorber and Savic (2011) compared the nursing leadership style, personality characteristics, and managerial competencies and determined the associations between these factors. The result showed that leaders rated themselves higher for vision and goals, communication, conflict resolution-agreement, compromise, adjustment, motivation, interpersonal relationships, problem-solving, delegation, teamwork, decision making, emotional intelligence, and human resources development.

Laguna et al. (2012) explained how managerial competencies relate to the business success of small and medium enterprises (SMEs) and provided some implications for interventions aiming at increasing successful SME management, by the development of the CEOs managerial competencies, which are not so stable but can be trained and modified. Bhardwaj and Punia (2013) identified competencies that are possessed by effective and successful managers across the world. They found that communication skills, team- working, reactiveness, vision, self-management, result-orientation, strategic- orientation, ambition, persistence, decision making, risk-taking, and creativity, are the commonly used managerial competencies by successful and effective managers. They have also found that it is very important for a business organization to assess the competencies of its managers and to determine skill gaps, to help the organization to develop effective training and development programs to enhance the competencies of its managers.

Raisiene (2014) showed that modern organizations should be managed with a new attitude to the manager's work, also a modern manager must be a leader who can enable employees and collaborate in a team. Asumeng (2014) provided a conceptual framework for a comprehensive and holistic generic managerial competency model building, which has implications for theory, practice, and empirical research. Hawi et al. (2015) explored the link between the managerial competencies and the firms' performance, they focus on the most effective managerial competencies in the airline's sector which has the greatest impact on performance. They found a positive relationship between the managerial competencies and the organization's performance in the airline's organizations in Jordan.

Veliul and Manxhari (2017) investigate the connections between managerial competency and performance of SMEs. The study showed the aspects that influencing the managerial competencies for good organizational performance. When organizations work seriously to apply the required managerial competencies, set them tasks they avoid the recruiting costs, dissatisfied customers, missed opportunities, and create their position in the market and drive success to organizations. It is therefore evident that the combinations of managerial competencies (professional, social, and personal) have an impact on the Performance of SMEs in Kosovo. Managerial competencies are not fixed and should correspond to the needs of the organization. Manxhari et al. (2017) aim to present models of managerial competencies from many authors. Managerial competencies are becoming one of the key building blocks of success of the company to achieve both the mission and vision in creating added value and improve business performance and especially the development of their people. A competency model is a tool for the detection and identification of needs for its development. The model's managerial competencies in many organizations have become an important part of human resources management. A competency model describes a specific combination of knowledge, skills, and other personality characteristics. They are necessary for the efficient execution of tasks in the organization. The competencies in a model may be organized in a variety of formats. Managerial competencies are not fixed and should correspond to the needs of the organization.

\section{Conceptual model}

The model used in this study was developed to examine the influence of managerial competencies on the business performance in the small business funded by Jordan River Foundation as shown in Figure1. 


\begin{tabular}{|c|c|c|}
\hline Managerial competencies & $\mathrm{H} 1$ & Business performance \\
\hline \multirow{3}{*}{$\begin{array}{ll}\text { - } & \text { Communication } \\
\text { - } & \text { Planning and organizing } \\
\text { - } & \text { Strategic thinking and scenario } \\
\text { building } \\
\text { - } \\
\text { - } \\
\text { Ceamwork } \\
\text { Customer focus }\end{array}$} & H11 & Efficiency \\
\hline & $\mathrm{H} 12$ & Sales performance \\
\hline & $\mathrm{H} 13$ & Customer satisfaction \\
\hline
\end{tabular}

Figure1. Conceptual model

Source: Prepared by the researcher based on: (Boyatz (1982); Choin-Kenney (1994); Kouzes and Posner (1995); Ulrich et al. (2000); Kotler \& Armstrong (2007); Minsky \& Kaufman (2008); Haycock (2012); Venkatraman and Ramanujam (1986); Sethi and King (1994)).

\section{Methodology}

\subsection{Measurement}

To test the main hypothesis of this research, a structured questionnaire instrument was designed for data collection to measure the influence of managerial competencies on the business performance in the small business funded by Jordan River, (See Appendix A). This questionnaire was adopted and combined by investigating previous researches and experts' suggestions. Under the research model, the questionnaires comprised two sections; the first section includes Demographic variables (Marital status, Age, Years of Experience, Qualifications, and Job position) that were measured using ordinal scales. The second section includes Managerial Competencies (communication, planning and organizing, strategic thinking and scenario building, teamwork, customer focus), and business performance (efficiency, sales performance, customer satisfaction). A five-point Likert scale ranging from "Strongly Disagree = 1" to "Strongly Agree = 5" was used to measure the items in the dimensions. The reliability estimates of the study for the various constructs under study are presented in Table (1).

Table1. Adoption of questions details, and reliability analysis of Managerial Competencies dimensions and Business Performance.

\begin{tabular}{|c|c|c|c|}
\hline Measured variables & Questions item & Cronbach's Alpha & Source \\
\hline Managerial competencies & 33 & 0.863 & \multirow{6}{*}{$\begin{array}{l}\text { Richard.E Boyatz (1982). Choin- } \\
\text { Kenney. L. (1994). Kouzes } \\
\text { J.M.and Posner, B.Z. (1995). } \\
\text { Intagliata, Ulrich \& Smallwood } \\
\text { (2000). Kotler \& Armstrong } \\
\text { (2007). Minsky \& Kaufman } \\
\text { (2008). Haycock (2012). }\end{array}$} \\
\hline Communication & 1 to 8 & 0.843 & \\
\hline Planning and organizing & 9 to 13 & 0.816 & \\
\hline $\begin{array}{l}\text { Strategic thinking and } \\
\text { scenario building }\end{array}$ & 14 to 22 & 0.760 & \\
\hline Teamwork & 23 to 28 & 0.860 & \\
\hline Customer focus & 29 to 33 & 0.879 & \\
\hline Business performance & 13 & 0.846 & \multirow{4}{*}{$\begin{array}{l}\text { Venkatraman and Ramanujam } \\
\text { (1986), Sethi and King (1994) }\end{array}$} \\
\hline Efficiency & 34 to 37 & 0.852 & \\
\hline Sales performance & 38 to 42 & 0.824 & \\
\hline customer satisfaction & 43 to 46 & 0.756 & \\
\hline Total & 46 & 0.882 & \\
\hline
\end{tabular}

\subsection{Sampling and Data Collection}

The sample consists of 220 small businesses funded by the Jordan River Foundation. Where 220 questionnaires were distributed to the study population composed of the managers of these businesses, 176 questionnaires with $80 \%$ were retrieved and valid to be analyzed.

\subsection{Characteristics of the Study Sample}

The demographic variables of the sample in terms of (social status, age, years of experience, qualifications, job position) was as shown in Table 2: 
Table 2. Demographic profile of participants $(n=176)$

\begin{tabular}{|l|l|l|l|}
\hline Variable & & Frequency & Percentage (\%) \\
\hline \multirow{4}{*}{ Marital Status } & Single & 61 & $34.7 \%$ \\
\cline { 2 - 4 } & Married & 72 & $40.9 \%$ \\
\cline { 2 - 4 } & Divorced & 19 & $10.8 \%$ \\
\cline { 2 - 4 } & Widow & 24 & $13.6 \%$ \\
\hline \multirow{5}{*}{ Yge } & Less than 25 & 39 & $22.2 \%$ \\
\cline { 2 - 4 } & from 25-less than 30 & 35 & $19.9 \%$ \\
\cline { 2 - 4 } & from 30-less than 35 & 51 & $29 \%$ \\
\cline { 2 - 4 } & From 35-less than 40 & 32 & $18.2 \%$ \\
\cline { 2 - 4 } & $40-$-and more & 19 & $10.8 \%$ \\
\hline \multirow{4}{*}{ Qualification } & 1 year- less than 6 & 52 & $29.5 \%$ \\
\cline { 2 - 4 } & From 6-less than 10 & 55 & $31.3 \%$ \\
\cline { 2 - 4 } & From 10-less than 15 & 43 & $24.4 \%$ \\
\cline { 2 - 4 } & From 15-less than 20 & 26 & $14.8 \%$ \\
\hline & Diploma and less & 60 & $34.1 \%$ \\
\cline { 2 - 4 } & Bachelor & 90 & $51.1 \%$ \\
\cline { 2 - 4 } & High educated & 26 & $14.8 \%$ \\
\hline
\end{tabular}

\section{Hypotheses Testing Results}

To test the study's hypotheses, simple and multiple regression analysis was carried out to determine the effect of managerial competencies on business performance. The result of (H1) in Table 3 showed a statistically significant influence of the managerial competencies (communication, planning and organizing, strategic thinking and scenario building, teamwork, and customer focus) on Business performance.

Table 3. Regression analysis for managerial competencies and business performance.

\begin{tabular}{|l|c|c|c|c|c|c|}
\hline Model & $\mathbf{r}$ & $\mathbf{r}^{\mathbf{2}}$ & $\boldsymbol{\beta}$ & $\mathbf{t}$ & $\mathbf{F}$ & Sig. \\
\hline Managerial competencies & .647 & .418 & .647 & 5.76 & 33.178 & $.000^{*}$ \\
\hline
\end{tabular}

Notes: * Denotes significance at the 0.05 level

The results of the multiple regression analysis (H11) shown in Table 4 revealed that managerial competencies are significantly correlated to business efficiency, communication has the highest correlation with efficiency $(\beta=$ $0.38, \mathrm{p}=0.03)$, followed by planning and organizing management competencies $(\beta=0.26, \mathrm{p}=0.04)$.

Table 4. Multiple Regression analysis for managerial competencies (communication, planning and organizing, strategic thinking and scenario building, teamwork, customer focus) and Efficiency

\begin{tabular}{|l|c|c|c|c|c|c|}
\hline Model & $\mathbf{B}$ & Std. Error & $\boldsymbol{\beta}$ & $\mathbf{t}$ & Sig. & $\mathbf{R}^{\mathbf{2}}$ \\
\hline (Constant) & 2.05 & 0.93 & & 2.22 & 0.03 & \\
\hline Communication & 0.41 & 0.11 & 0.38 & 2.6 & $0.03^{*}$ \\
\hline Planning and organizing & 0.29 & 0.10 & 0.26 & 2.41 & $0.04^{*}$ & \multirow{2}{*}{0.23} \\
\hline Strategic thinking and scenario building & -0.05 & 0.15 & -0.03 & -0.30 & 0.76 \\
\hline Teamwork & 0.18 & 0.16 & 0.09 & 1.10 & 0.27 \\
\hline Customer focus & 0.22 & 0.16 & 0.12 & 1.45 & 0.15 & \\
\hline
\end{tabular}

Note: * Denotes significance at the 0.05 level

The results of the multiple regression analysis (H12) shown in Table 5 revealed that managerial competencies are significantly correlated to sales performance, customer focus has the highest correlation with sales performance $(\beta=0.35, p=0.00)$, followed by communication management competencies $(\beta=0.18, p=0.03)$, and lastly planning and organizing management competencies $(\beta=0.16, \mathrm{p}=0.04)$.

Table 5. Multiple Regression analysis for managerial competencies (communication, planning and organizing, strategic thinking and scenario building, teamwork, customer focus) and Sales Performance

\begin{tabular}{|l|c|c|c|c|c|c|}
\hline Model & $\mathbf{B}$ & Std. Error & $\boldsymbol{\beta}$ & $\mathbf{t}$ & Sig. & $\mathbf{R}^{\mathbf{2}}$ \\
\hline (Constant) & 1.53 & 0.53 & & 2.90 & 0.00 & \\
\hline Communication & 0.21 & 0.11 & 0.18 & 2.4 & $0.03^{*}$ \\
\hline Planning and organizing & 0.19 & 0.10 & 0.16 & 2.01 & $0.04^{*}$ & \multirow{2}{*}{0.44} \\
\hline Strategic thinking and scenario building & -0.01 & 0.08 & -0.01 & -0.02 & 0.99 \\
\hline Teamwork & 0.03 & 0.09 & 0.03 & 0.36 & 0.72 \\
\hline Customer focus & 0.39 & 0.09 & 0.35 & 4.41 & $0.00^{*}$ & \\
\hline
\end{tabular}

Note: * Denotes significance at the 0.05 level

The results of the multiple regression analysis (H13) shown in Table 6 revealed that managerial competencies are significantly correlated to customer satisfaction, customer focus has the highest correlation with sales 
performance $(\beta=0.19, p=0.02)$, followed by communication management competencies $(\beta=0.18, p=0.04)$, and lastly teamwork management competencies $(\beta=0.16, \mathrm{p}=0.04)$.

Table 6. Multiple Regression analysis for managerial competencies (communication, planning and organizing, strategic thinking and scenario building, teamwork, customer focus) and Customer Satisfaction

\begin{tabular}{|l|c|c|c|c|c|c|}
\hline Model & B & Std. Error & $\boldsymbol{\beta}$ & $\mathbf{t}$ & Sig. & $\mathbf{R}^{\mathbf{2}}$ \\
\hline (Constant) & 3.03 & 1.33 & & 2.29 & 0.02 & \\
\hline Communication & 0.55 & 0.26 & 0.18 & 2.11 & $0.04^{*}$ \\
\hline Planning and organizing & 0.34 & 0.24 & 0.13 & 1.45 & 0.15 & \multirow{2}{*}{0.58} \\
\hline Strategic thinking and scenario building & -0.09 & 0.21 & -0.04 & -0.44 & 0.66 & \\
\hline Teamwork & 0.38 & 0.23 & 0.17 & 1.99 & $0.04^{*}$ \\
\hline Customer focus & 0.48 & 0.22 & 0.19 & 2.20 & $0.02^{*}$ & \\
\hline
\end{tabular}

Note: * Denotes significance at the 0.05 level

\section{Discussion}

This study aims to identify the relationship between managerial competencies (communication, planning and organizing, strategic thinking and scenario building, teamwork, and customer focus) and small business performance. The results showed that H1, H11, H12, and H13 are significantly supported. The results showed a statistically significant influence of the managerial competencies (communication, planning and organizing, strategic thinking and scenario building, teamwork, and customer focus) on business performance in the small business funded by the Jordanian River Foundation. This results in similarity with the study of Olawale (2014) that there is a statistically significant relationship between the level of experience and performance. Business owners who have previous work experience before a business establishment significantly perform better than those without prior experience. It also showed a similarity with the study Agota (2014) that modern organizations must be managed with a new attitude of the work of the manager, who must be a leader who can empower staff and cooperate in teams and supporting the result of Petra et al. (2013) which shows a relationship between managerial competencies and organizational performance.

This study also found that the managerial competencies (communication, planning and organizing, strategic thinking and scenario building, teamwork, and customer focus) are important in contributing to business efficiency, sales performance, and customer satisfaction. Generally, this study confirms that managerial competencies among small businesses play a crucial role in the success of middle managers as argued by Qiao and Wang (2008). Consistent with Krajcovicova et al. (2012), which showed that managerial competencies are critical to achieving results that are consistent with the strategic goals of the organization. Before that, Abraham et al. (2001) found that the most important competency areas are leadership skills, customer focus, result orientation, problem-solving, communication skills, and team leader to be an effective manager. Moreover, Hellriegel, et al. (2005) added that communication competency, planning and administration competency, teamwork competency, strategic action competency, global awareness competency, and self-management competency as the six core managerial competencies which are required to be an effective manager to give high performance.

\section{Conclusion and Managerial implications}

This study examined the relationship between managerial competencies dimensions (communication, planning and organizing, strategic thinking and scenario building, teamwork, and customer focus competency) and business performance. By using a self-administered questionnaire, 176 samples were collected from small business managers. The results confirmed that managerial competencies, namely communication, planning and organizing, strategic thinking and scenario building, teamwork, and customer focus had significant influences on small business performance. It consolidates theories that managerial competencies explained business performance. Despite its contributions, this study also has several limitations and drawbacks. It is limited to closed-ended questions, where responses were fixed to a set of predetermined questions. The respondents did not have the opportunity to provide additional input and comments. Thus, future research should modify the questions by adopting a mixed format, enabling the respondents to furnish additional input and comments. The research was limited to small businesses funded by the Jordan River Foundation only. A broader geographic sampling to include more large urban and rural areas would better reflect the national profile. Future research may be strengthened by using a sample comprising a more diverse set of businesses.

Another approach could be to conduct a longitudinal nationwide study to identify the factors that hinder small business performance. Future research should collect data on a longitudinal basis to help draw causal inferences and validate the findings of this study. In terms of competencies construct, this study focused and adapted the managerial competencies which consist of communication, planning and organizing, strategic thinking and scenario building, teamwork, and customer focus competency, while there are many more competencies. Future researchers could extend this study by examining and adding more components and variables associated with managerial competencies relevant to small business managers. 


\section{References}

Abraham, S.; Karns, L.; Shaw, K.; Mena, M. (2001). Managerial competencies and the managerial performance appraisal process. Journal of Management Development, 20(10), 842-852.

Armstrong, M. (2006). Performance Management: Key Strategies and Practical Guideline. 3rd ed. Kogan Page Limited.

Asumeng, M. (2014). Managerial Competency Models: a Critical Review and Proposed Holistic-Domain Model. Journal of Management Research. 3(4), 6-4.

Bhardwaj, A., Punia, B.K. (2013). Managerial Competencies and Their Influence on Managerial Performance: A Literature Review. International Journal of Advanced Research in Management and Social Sciences, 2 (5), 70-84

Boyatzis, R. (1982). The competent manager: A model for effective performance. John Wiley \& Sons.New York.

Bueren, A; Schierholz, R. and Kolbe, L. (2004). Customer Knowledge Management Improving Performance of Customer Relationship Management with Knowledge Management. In System Sciences. Proceedings of the 37th Annual Hawaii International Conference. 4(1). 1-10.

Casimir, G., \& Waldman, D. A. (2007). A cross-cultural comparison of the importance of leadership traits for effective low-level and high-level leaders: Australia and China. International Journal of Cross-Cultural Management, 7(1), 47-60. DOI: 10.1177/1470595807075171

Chion-Kenney, L. (1994). Site-Based Management and Decision Making: Problems and Solutions. American Association of School Administrators.

Chong, A. (2011). Can Malaysian Firms Improve Organizational/Innovation Performance Via SCM? Industrial Management \& Data Systems, 111(3), 410-431.

Chye, L., Tat, H., Osman, M., Rasli, A., \& Md, A. (2010). Are managerial Competencies a Blessing to the Performance of Innovative SMEs in Malaysia. International Journal of Economics and Management, 2(5).105-113.

Cockerill, T. (1989). The Kinds of Competence for Rapid Change. Personnel Management, 21(9), 52-60.

Collins, C. J. \& Clark, K. D. (2003). Strategic Human Resource Practices, Top Management Team Social Networks, and Firm Performance: The Role of Human Resource Practices in Creating Organizational Competitive Advantage. Academy of Management Journal. 4(9), 509-521.

Durrani, B., Obaid U. \& Sabeeh U. (2011). Effect of Leadership on Employees Performance in Multinational Pharmaceutical Companies in Pakistan. Interdisciplinary Journal of Contemporary Research in Business. 2(9), 286-299.

Gladon, N., and Augustine, A. (2008). Managerial Competencies and Marketing Effectiveness in Corporate Organizations in Nigeria. Journal of Management Development. (5), 666-679.

Harold (1993). The Measurement of Productive Efficiency: Techniques and Applications: Techniques and Applications. Oxford University Press, USA.1St edition

Hawi, R., Alkhodary, D., and Hashem, T. (2015). Managerial Competencies and Organizations Performance. International Journal of Management Sciences. 5(11), 723-735.

.Haycock (2012). Strategic Thinking and Leadership. Library Leadership \& Management. (4), 4-26.

Heene \& Sanchez (1997). Competence-based strategic management. London: Wiley. (5).65-74.

Hellriegel, D., Jackson, S.E. \& Slocum, J.J. (2005). Management: A Competence-Based Approach. Singapore: Thomson South-Western

Hoffmann, T. (1999). The meanings of competency. Journal of European Industrial Training. 23(6), 275-286.

Hogg, M. A. (2001). A social identity theory of leadership. Personality and social psychology review. 5(3), 184200.

Kotler, P. Armstrong, G. and Opresnik, M. (2018). Principles of Marketing. 17th ed, Global Edition. Pearson Education Limited

Kouzes, J.M. and Posner, B.Z. (1995). Credibility: How Leaders Gain and Lose It, Why People Demand It. San Francisco: Jossey-Bass.

Krajcovicova, K., Caganova, D., \& Cambal, M. (2012). Key managerial competencies and competency models in industrial enterprises. In Annals of DAAAM for 2012 and Proceedings of the 23rd International DAAAM Symposium. 23(1).1-23.

Laguna, M., Wiechetek, M., Talik, W. (2012). Competencies of Managers and Their Business Success. Central European Business Review. 1(3).7-13.

Lorber, M., \& Skela Savič, B. (2011). Perceptions of Managerial Competencies, Style, and Characteristics Among Professionals in Nursing. Croatian Medical Journal. 52(2),198-204.

Manxhari, M.; Veliu, L.; and Jashari, J. Developing Models of Managerial Competencies of Managers: A Review. International Journal of Economics, Commerce and Management United Kingdom. (4), 186-200.

Masoud, E. and Alzayat, L. (2012). The Effect of Training and Top Management Support on Frontline Employees' Performance in Service Sector in Jordan. An-Najah University Journal for Research, 26(8), 1761-1796. 
Masoud, E. (2020). The Effect of Service Quality on Customers' Satisfaction in Mobile Phone Services in the UAE. Transnational Marketing Journal, 8(1), 75-94.

Minsky \& Kaufman (2008). Stabilizing an unstable economy. 1st Ed. McGraw-Hill.

Qiao, J. \& Wang, W. (2009). Managerial Competencies for Middle Managers: Some Empirical Findings from China. Journal of European Industrial Training. (4), 44-50.

Raisiene, A. (2014). Leadership and managerial competences in a contemporary organization from the standpoint of Business Executives. Economics \& Sociology. 7(3) .100-179.

Rao, T. V. (2007). Global leadership and managerial competencies of Indian managers. Indian Institute of Management, W.P. No. 2007-06-05, 1-29.

Riketta, M. (2002). Attitudinal Organizational Commitment and Job Performance: A Meta-Analysis. Journal of organizational behavior. 23(3), 257-266.

Sethi, V., \& King, W.R. (1994). Development of Measures to Assess the Extent to Which an Information Technology Application Provides Competitive Advantage. Management Science. 40(12), 1601-1627.

Smart, Bradfort D. (1999). Top grading: how leading companies win by hiring, coaching and keeping the best people. Englewood Cliffs: Prentice Hall, New York

Sparrow, P. (2016). Strategic HRM, Innovation and HR Delivery for Human Resource Management, Innovation, and Performance. In Human Resource Management, Innovation and Performance. 15-31.

Ulrich, D \& Lake, D. (1991). Organizational capability: Creating competitive advantage. The Executive. 5(1). $77-$ 92.

Ulrich, D.; Zenger, J. and Smallwood, N. (2000). Building Your Leadership Brand, Leader to Leader. Winter 2000, 40-46.

Veliul, L, and Manxhari, M. (2017) The Impact of Managerial Competencies on Business Performance: SME's IN Kosovo. Vadyba Journal of Management. 1(30), 59-65.

Venkatraman, N. \& Ramanujam, V. (1986). Measurement of Business Performance in Strategy Research: A Comparison of Approaches. Academy of Management Review. 11(4), 801-814.

Xuejun, J. \& Wei Wang, W. (2009). Managerial Competencies for Middle Managers: Some Empirical Findings from China. Journal of European Industrial Training. 33(1), 69-81.

\section{Appendix A}

Proposed Measurement Items for Constructs

\begin{tabular}{|c|c|c|c|c|}
\hline Constructs & Items & Measurement items & Mean & $\begin{array}{l}\text { Std. } \\
\text { Dev. }\end{array}$ \\
\hline \multirow{9}{*}{$\begin{array}{r}\text { Communication } \\
\text { (1 to } 8)\end{array}$} & Com & & 4.021 & .6510 \\
\hline & 1 & $\begin{array}{l}\text { Communication in my company is very effective in } \\
\text { employees' behaviors. }\end{array}$ & 4.38 & 0.90 \\
\hline & 2 & Giving customers the right amount of eye contact. & 4.42 & 0.66 \\
\hline & 3 & Giving customers my best smile. & 4.33 & 0.72 \\
\hline & 4 & $\begin{array}{l}\text { I used to describe situations when I had to convince } \\
\text { others. }\end{array}$ & 4.31 & 0.80 \\
\hline & 5 & $\begin{array}{l}\text { I give examples when I had to present complex } \\
\text { information. }\end{array}$ & 4.53 & 0.64 \\
\hline & 6 & $\begin{array}{l}\text { I used to establish good communication and } \\
\text { information flow with others. }\end{array}$ & 4.36 & 0.64 \\
\hline & 7 & $\begin{array}{l}\text { Using conversation impressions to communicate } \\
\text { effectively with others. }\end{array}$ & 4.31 & 0.83 \\
\hline & 8 & $\begin{array}{l}\text { I used to show an interest in what another person is } \\
\text { saying. }\end{array}$ & 4.34 & 0.76 \\
\hline \multirow{6}{*}{$\begin{array}{l}\text { Planning and organizing } \\
(9 \text { to } 13)\end{array}$} & $\mathrm{PO}$ & & 3.598 & .9434 \\
\hline & 9 & I used to clarify an existing strategic plan. & 4.40 & 0.70 \\
\hline & 10 & $\begin{array}{l}\text { I take steps that organize a business plan for a new } \\
\text { project. }\end{array}$ & 4.53 & 0.60 \\
\hline & 11 & Consulting with others before making a decision. & 4.38 & 0.81 \\
\hline & 12 & $\begin{array}{l}\text { I used to explain my general decision-making } \\
\text { process. }\end{array}$ & 4.30 & 0.83 \\
\hline & 13 & $\begin{array}{l}\text { I used to give examples of a situation where you } \\
\text { had to make a decision when you didn't have all the } \\
\text { facts. }\end{array}$ & 4.44 & 0.71 \\
\hline
\end{tabular}




\begin{tabular}{|c|c|c|c|c|}
\hline Constructs & Items & Measurement items & Mean & $\begin{array}{l}\text { Std. } \\
\text { Dev. }\end{array}$ \\
\hline \multirow{10}{*}{$\begin{array}{l}\text { Strategic thinking and } \\
\text { scenario building } \\
(14 \text { to } 22)\end{array}$} & ST & & 3.712 & .8332 \\
\hline & 14 & Sharing ideas to establish critical thinking. & 4.09 & 0.96 \\
\hline & 15 & I share responsibility with staff members. & 4.43 & 0.71 \\
\hline & 16 & Creating a clear vision for the organization. & 4.52 & 0.66 \\
\hline & 17 & $\begin{array}{l}\text { I make a strong staff relationship based on open } \\
\text { communication. }\end{array}$ & 4.47 & 0.75 \\
\hline & 18 & Using data to help ground decision making. & 4.35 & 0.76 \\
\hline & 19 & $\begin{array}{l}\text { Learning from the experience of others - good and } \\
\text { bad. }\end{array}$ & 4.36 & 0.76 \\
\hline & 20 & $\begin{array}{l}\text { Knowing how to succeed and decide how to hold } \\
\text { yourself accountable. }\end{array}$ & 4.45 & 0.67 \\
\hline & 21 & $\begin{array}{l}\text { I used to assess organizational strengths and } \\
\text { challenges. }\end{array}$ & 4.45 & 0.78 \\
\hline & 22 & Describing a problem by collecting information & 4.36 & 0.77 \\
\hline \multirow{7}{*}{$\begin{array}{l}\text { Teamwork } \\
(23 \text { to } 28)\end{array}$} & TW & & 3.746 & .8541 \\
\hline & 23 & My team's dynamics help me to work well together. & 4.24 & 0.91 \\
\hline & 24 & My team members improving my competencies. & 4.30 & 0.85 \\
\hline & 25 & My company provides the training I need. & 4.33 & 0.77 \\
\hline & 26 & I have a strong common identity with my team. & 4.44 & 0.71 \\
\hline & 27 & I share information with others. & 4.27 & 0.91 \\
\hline & 28 & My team adjusts to changing priorities quickly. & 4.41 & 0.72 \\
\hline \multirow{6}{*}{$\begin{array}{l}\text { Customer focus } \\
(29 \text { to } 33)\end{array}$} & $\mathrm{CF}$ & & 3.631 & .8528 \\
\hline & 29 & $\begin{array}{l}\text { My competitive advantage is based on } \\
\text { understanding customers' needs. }\end{array}$ & 4.34 & 0.81 \\
\hline & 30 & $\begin{array}{l}\text { My relationship with my major customers is strong } \\
\text { and loyal. }\end{array}$ & 4.31 & 0.81 \\
\hline & 31 & $\begin{array}{l}\text { I regularly discuss competitors 'strengths and } \\
\text { weaknesses to gain more customers from them. }\end{array}$ & 4.26 & 0.93 \\
\hline & 32 & $\begin{array}{l}\text { I should increase the number of new customers } \\
\text { frequently by improving my product. }\end{array}$ & 4.45 & 0.75 \\
\hline & 33 & $\begin{array}{l}\text { I believe that analyzing and responding to } \\
\text { the competitor's action is crucial to maintain my } \\
\text { competitive advantage. }\end{array}$ & 4.47 & 0.72 \\
\hline \multirow{5}{*}{$\begin{array}{l}\text { Efficiency } \\
\text { (34 to } 37)\end{array}$} & Eff & & 3.700 & .8630 \\
\hline & 34 & Putting enough time and effort into my work. & 4.41 & 0.72 \\
\hline & 35 & The training program is helpful in personal growth. & 4.39 & 0.67 \\
\hline & 36 & Make sure that your business is making a profit. & 4.41 & 0.63 \\
\hline & 37 & Working in the right business area. & 4.36 & 0.71 \\
\hline \multirow{6}{*}{$\begin{array}{l}\text { Sales performance } \\
(38 \text { to } 42)\end{array}$} & SP & & 3.604 & 1.087 \\
\hline & 38 & $\begin{array}{l}\text { The prices of my products have to be changed from } \\
\text { time to time to attract more customers }\end{array}$ & 4.40 & 0.77 \\
\hline & 39 & The sales volume of our products has increased. & 4.40 & 0.71 \\
\hline & 40 & I pay close attention to after-sales service. & 4.17 & 0.96 \\
\hline & 41 & The market share of our products has increased. & 4.31 & 0.76 \\
\hline & 42 & Our customers are increasing frequently & 4.31 & 0.83 \\
\hline \multirow{5}{*}{$\begin{array}{l}\text { Customer satisfaction } \\
\text { ( } 43 \text { to } 46)\end{array}$} & $\mathrm{CS}$ & & & \\
\hline & 43 & My customers are more satisfied with my product & 4.16 & 0.86 \\
\hline & 44 & $\begin{array}{l}\text { I used to ensure that customers are more loyal to } \\
\text { my company than before }\end{array}$ & 4.27 & 0.82 \\
\hline & 45 & $\begin{array}{l}\text { I respond rapidly to my customers' changes in } \\
\text { interests }\end{array}$ & 4.35 & 0.87 \\
\hline & 46 & $\begin{array}{l}\text { I always ensure that my products meet the exact } \\
\text { expectations of my customers }\end{array}$ & 4.31 & 0.90 \\
\hline
\end{tabular}

